\title{
I. Dünya Savaşı'nda Erzurum Vilayetinin Demografisine Dair Tespitler
}

Yakup Karataş ***

Ağrı İbrahim Çeçen Üniversitesi, Fen-Edebiyat Fakültesi, Tarih Bölümü, Ağrı, Türkiye

* Bu çalışma 12-14 Kasım 2015 tarihlerinde İzmir 9 Eylül Üniversitesinde Türk Tarih Kurumu tarafindan düzenlenen Uluslararası I. Dünya Savaşı Sempozyumu (Türk-Rus Penceresi)'nda takdim edilmiş sözlü bildirinin düzenlenmiş ve gözden geçirilmiş halidir.

Makale Bilgileri / Article Info: Gönderim / Received: 04.02.2018 Kabul / Accepted: 25.05.2018
** Sorumlu Yazar / Corresponding Author:

Ağrı İbrahim Çeçen Üniversitesi, Ağrı, Türkiye ykaratas@agri.edu.tr

\section{$\ddot{O} \mathbf{z}$}

Savaşlar ve özellikle dünya savaşları toplumlar ve kurumlar üzerinde çok ciddi tahribat yapan süreçlerdir. Bilhassa I. Dünya Savaşı küresel ittifak sistemlerinin karşı karşıya geldiği ilk örneklerden olarak dünya tarihi açısından o zamana dek benzeri görülmemiş felaketlere yol açmıştır. Siyaset, demografi, şehirleşme ve iskân gibi pek çok alanda bir dönüm noktası olarak ele alınan bu büyük hadisenin demografik boyutunun büyüklüğünün, yaşanan göçler ve ölümlerle birlikte daha iyi anlaşılacağı açıktır. Bugüne dek yapılan pek çok nicel değerlendirme bu mevzuya $1 s ̧ 1 \mathrm{k}$ tutmuştur. Kaybın sayısal olarak tespit edilebilmesi için nüfusun ve göç vetiresinin rakamlarla ele alınması da bir zorunluluktur. İsgal ve istila durumlarında müstevli güçler işgal ettikleri bölgelerin nüfus ve tapu gibi kayıtlarını da ya imha etmiş ya da beraberlerinde ülkelerine götürmüşlerdir. Bu çalışmada arşiv belgelerinin 1şı̆̆ında, I. Dünya Savaşı sırasında Erzurum Vilayetinin nüfusu ile ilgili tespit ve mülahazalara yer verilecektir. Zira yüz yıl önce coğrafi olarak Doğu Anadolu'nun önemli bir kısmını teşkil eden Erzurum Vilayeti, ihtiva ettiği sancaklarıyla birlikte işgal ve istila edilmiş, ahali ve şehir ciddi kayıplar yaşamıştı. Bu vesile ile nüfus gibi -Ermeni iddiaları da göz önünde bulundurulduğunda- önemli bir tartışma sahasında ortaya konan belgelerle Erzurum'daki demografik hareketlilikler incelenecektir. Başbakanlık Osmanlı Arşivi kapsamında bulunan Dâhiliye Nezareti'nin Sicill-i Nüfus, Şifre ve İdare-i Umumiye gibi fonlarından elde edilen verilerle Erzurum vilayeti ve bağlı sancakların savaş öncesi ve sonrasındaki demografik yapısı üzerinde durulacaktır. Netice itibariyle hem savaşın tahripkâr etkileri bir kez daha ortaya konmuş hem de Erzurum gibi özel bir bölgenin savaştan nasıl etkilendiği aydınlatılmış olacaktır.

Anahtar Kelimeler: I. Dünya Savaşı, Erzurum Vilayeti, Nüfus ve Demografi, Arşiv Kayıtları.

\footnotetext{
Atıf için / To cite this article: doi: $10.30613 /$ curesosc.389964

Karataş, Y. (2018). I. Dünya Savaşı'nda Erzurum vilayetinin demografisine dair tespitler. Curr Res Soc Sci, 4(2), 48-59. 


\section{Determinations on Demography of Erzurum during the World War I}

\section{Abstract}

Wars and especially world wars are very destructive processes for societies and institutions. Exclusively World War I, as one of examples of global alliance systems had fought, caused widely calamities those haven't seen before in world history. Magnitude of this important event which has accepted as a landmark in terms of policy, demography, urbanism and settlements, would be more clear with numericals of migrations and deceases. Lots of quantitative evaluations had enlighten this point till now. Handling the population and migration process is an obligation to determine the numerical of losses. During the occupations and invasions, the invaders had destroyed or carried the registers of population and deeds to their own countries near them. In this paper some determinations and evaluations took place under the light of archival records of population of Province of Erzurum during the World War I. Forasmuch the province was geographically the biggest part of Eastern Anatolia had missed lots of people and urban values under the invasion with its districts and the other subunits a hundred years ago. Hereby population movements in Erzurum will be analysed by the records on an important debate field just as "population" -if Armenian claims also be considered-. Demographic structure of Erzurum before and after the war will be handled by acquired data from the funds of Personal Records, Telegraph and Police Headquarters of Ministry of Internal Affairs of Ottoman Archive. As a result, destructive effects of the war to a specific place such as Erzurum will be illuminated.

Keywords: World War I, Province of Erzurum, Population and Demography, Archival Records.

\section{Giriş}

Sanayileşmiş Avrupa ülkeleri arasında dünya hâkimiyetini ele geçirmek amacıyla 1870'lerden itibaren kurulan ittifak blokları arasındaki gerilim XX. yüzyılın ilk on yılında oldukça artmış ve nihayetinde Birinci Dünya Savaşı çıkmıştır. Savaş sirasında "İtilaf" ve "İttifak" devletleri olarak karşı karşıya gelen taraflar arasına başka devletler de katılmış, bloklar arasında geçişler yaşanmış, kimi devletler de savaşın ortasında kendi iç gelişmeleri dolayısıyla savaştan çekilmek zorunda kalmıştır (Kuran, 1992, ss. 196-198). Savaşan taraflar 19. yy. savaşlarından farklı olarak savaş ekonomisi koşulları içinde tüm insan gücü ve iktisadi kaynaklarını kullandıklarından siviller de cephedekiler kadar savaştan etkilenmişlerdir. (Ballı, ty., s. 861) Dolayısıyla nüfus ve demografi sorunlarını savaşın yol açtığı sorunların en önemlilerinden saymak mümkündür. Osmanlı Devleti de olası bir savaşta İngiliz, Fransız ve Rusların meydana getirdiği itilaf bloğuna dâhil olmak istemiş ise de iç ve diş gelişmelerle devletlerarası siyasi parametreler Osmanlı yöneticilerini Almanya'nın da içinde bulunduğu ittifak devletleri arasında yer almaya zorlamıştır (Ahmad, 1985, ss. 298-301). Osmanlı Devleti Birinci Dünya Savaşı'na zamanın ve şartların da zorlamasıyla; 1911-1912 Trablusgarp ve 19121913 Balkan Savaşları ile kaybettiği toprakları geri kazanma, uluslararası politik yalnızlıtan kurtulma ve yabancı devletlerin kendi toprakları üzerindeki paylaşım hesaplarını boşa çıkarma gibi amaçlarla girmiştir. Avrupa'da başlayan savaş Osmanlı'nın müdahil olmasıyla Ön Asya'ya da yayılmıştır (Uçarol, 2000, ss. 465-469) Komuta kademesindeki bölünmüşlük, ekonomik sıkıntılar, askerin sevk ve idaresinde yaşanan zaafların yanı sıra kendi topraklarında Kafkas, Süveyş Kanalı, Çanakkale, Suriye ve Irak ile sınırlar dışında müttefiklere yardım amacıyla iştirak edilen Galiçya, Dobruca ve Makedonya gibi cephelerin birbirine uzaklığı, Osmanlı Devleti'ni savaş sırasında oldukça elverişsiz şartlar içinde bırakmıştır (Karal, 1999, s. 411). Çanakkale cephesindeki başarılı savunma harekâtının yanı sıra çeşitli cephelerde elde edilen kısmi ve taktiksel başarılar yaşanan mağlubiyete engel olamamış, Almanlarla birlikte Osmanlı Devleti de savaştan yenilgi ile ayrilarak yıkılış sürecine girmiştir. 1914-1918 yılları arasında dört yıl, üç ay, on bir gün süren I. Dünya Savaşı maddi ve manevi pek büyük hasarlar meydana getirmiştir. Netice itibariyle Osmanlı Devleti savaş öncesindeki kayıpların telafisine yönelik amaçlarını gerçekleştirememenin yanında fiilen son bulma noktasına gelmiştir. 
$\mathrm{Bu}$ çalışmada I. Dünya Savaşı sırasında Erzurum Vilayeti ve Erzurum şehrinin nüfusu ve savaştan kaynaklanan şartların zorlaması ile nüfus hareketliliklerinin demografiye etkileri üzerinde durulmuştur. Oldukça tartışmalı bir alan üzerinde yürütülen bu çalışmada en doğru tespitlerin yapılabilmesi adına; kayıtlarla ilgili olarak Osmanlı Devleti'nin Dâhiliye Nezareti Sicill-i Nüfus İdaresinin yazışmalarından, resmi istatistiklerden, birimler arası yazışmaları konu alan Dâhiliye Şifre Kalemi evrakından, vali raporlarını ihtiva eden Dâhiliye İdare-i Umumiye belgelerinden ve bilimsel kıymeti haiz yerli ve yabancı araştırmacıların tespitlerinden istifade edilmiştir. Elde edilen arşiv belgeleri, tarihlendirmeleri yapılarak kronoloji çerçevesinde konu bütünlüğü içindeki yerlerine yerleştirilmiştir. Nüfus konusunda kaynaklar arasında ortaya çıkan tutarsızlıkların sebepleri araştırılmış ve verilerin farklılıkları yorumlanmıştır. Salt tarihi realite göz önünde bulundurularak sübjektif değerlendirmelerden uzak bir şekilde nüfus ve demografi ile ilgili tespitlere yer verilmiştir. İsgalden dolayı nüfus, tapu ve askerlik kayıtları gibi veri bankalarının imha edilmiş olması nedeniyle merkezi bürolardan elde edilen tüm sayılar önemle incelenmiş ve ilgili her rakam ciddiyetle ele alınmıştır.

Elde edilen verilerin takdiminde öncelikle I. Dünya Savaşına gidilen süreç ile Osmanlı Devleti'nin savaşa dahil olması ele alınmış, Kafkas cephesi bağlamında Rusların Erzurum'a kadar ilerlemesi üzerinde durulmuştur. Rus ordularının çekilme süreci tartışlarak Rus askerlerinin yerini alan Ermeni çetelerinin başlattığı katliamlar detaylandırılmıştır. $\mathrm{Bu}$ gelişmelerin vilayetin şehir dokusuna, nüfusuna ve toplumsal yapısına tesirleri incelenmiştir. Göç konsepti üzerinde durularak bunun Erzurum'da nasıl gerçekleştiği değerlendirilmiş, savaş öncesi ve sonrasındaki nüfus sayıları mukayese edilmiştir. Nihayette Türkiye Cumhuriyeti'nin ilk nüfus sayımı olan 1927 sayımında elde edilen rakamlar yorumlanarak savaşın etkileri üzerinde genel bir tablo çizilmiştir. Konu bütünlüğünün bozulmaması için yer yer notlar ilave edilmiş ve bunlar kaynakça öncesinde toplu olarak gösterilmiştir.

\section{Kafkas Cephesi Muharebeleri ve Erzurum'un İşgali}

$\mathrm{Bu}$ çalışmanın konusunu kısmen teşkil eden Kafkas Cephesi, I. Dünya Savaşı'nda Ruslara karşı açılmış bir taarruz cephesiydi. Zira bu cephede saldırılıp Rusların püskürtülmesi ile Kafkasya yolunun açılacağı hesap edilmekteydi. Osmanlı askerî erkânı her ne kadar Rusya'nın saldirmasina ihtimal vermiyor idiyse de ihtiyati tedbirlerden de geri durulmuyordu. Yavuz (Goeben) Zirhlısının Rusya'nın Sivastopol limanına taarruzu üzerine (29 Ekim 1914) Ruslar Osmanlı'ya karşı savaş ilan etmiş ve Kaleboğazı, Kötek, Veli Baba, Karakilise ve Eleşkirt dolaylarından taarruza başlayarak Erzurum'a yönelmişlerdi. $\mathrm{Bu}$ ilk safhada özellikle Köprüköy'de ağır zayiat veren Ruslar geri çekilmek zorunda kalmışlardı. Aras Nehri'nin güney mevzilerindeki askeri kıtalara destek veren Erzurumlulardan yaralanan veya şehit olanların sayıs1 toplam 5000'i bulmuştu (Som, 2005, s. 95). $\mathrm{Bu}$ galibiyet üzerine Artvin, Çoruh, Ardahan ve Oltu Türkler tarafından kurtarılmıştı (Kurat, 2014, s. 444). Sivas'ta içtima ederek kırk beş günlük bir yolun ardından gecikmeli de olsa Erzurum'a ulaşan 13. Kolordu'nun ilavesi, diğer lojistik ve istihkâmların da tekmiliyle yaklaşık 150.000 kişilik bir ordunun ihtiyaçlarına yetecek donanım hazırland1 (Som, 2005, s. 96).

22 Aralık 1914'ten başlayıp 29 Aralık'a kadar devam eden Türk taarruzu; çeşitli komuta hataları, ikmal imkânlarının yetersizliği, firarlar, salgın hastalıklar ve soğuğun da etkisiyle istenen sonucu vermemiş ve 29-30 Aralık günlerinde obüs topları ile tahkim edilen Rus birliklerinin ateş üstünlüğünü ele geçirmesi ile Sarıkamış’ta siper savaşları başlamıştı. Yaklaşık dört gün süren siper savaşları sonunda Sarıkamış'ta sayıları artan Rus askerlerinin taarruz harekâtına başlaması üzerine 3-4 Ocak 1915'te Türk ordusunda geri çekilme tezahürleri başladı. Savaşın diğer cephelerdeki seyrine rağmen Ruslar yaklaşık bir yıl ele geçirdiği yerlerde kaldı. 1916 Şubatı'nda Doğu Cephesine saldıran Ruslar Erzurum, Trabzon ve 
Erzincan'a girdiler. Çok sert geçen 1916-1917 kışında Rusların yaklaşık 100.000 kayıp verdiği tahmin edilmektedir (Balc1, 2005). ${ }^{\mathrm{i}}$ Asker ve teçhizatlarının çokluğu nedeniyle Doğu Anadolu ve hatta İran'da kolayca ilerleyen Ruslar, 16 Şubat 1916'da Erzurum daha sonra da Muş, Bitlis, Trabzon ve Erzincan'1 ele geçirdiler. Miralay Fevzi Bey komutasındaki Türk birlikleri Ruslara karşı mevzii denebilecek başarılar elde ettiyse de harbin Ruslar lehine gelişmesine engel olunamadi. Durum böyle iken 1917 yılında Rusya'da ihtilal

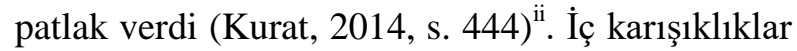
yaşayan Ruslar savaştan çekilme kararı alarak 15 Aralık 1917'de İttifak Devletleri ile Brest-Litovsk Mütarekesini imzaladılar. 18 Aralık 1917'deki Erzincan Mütarekesi ile de Osmanl1-Rus Savaş1 nihayete erdirildi. Ruslar 3 Mart 1918'deki BrestLitovsk Antlaşması ile de işgal ve istila ettiği yerlerden çekilmeyi taahhüt etti (Uçarol, 2000, s. 476). Hatta hem ortak antlaşmada hem de yine 3 Martta Ruslarla Brest-Litovsk'ta imzalanan 15 maddelik bir "Ek Antlaşma" da Ruslar, 1877-1878 Savaşı'ndan önceki sınırlara çekiliyor, bu suretle Kars, Ardahan ve Batum'u bölgede tabiiyet hususunda halk oylaması yapılması üzere terk ediyordu (Uçarol, 2000, s. 478) iii. Bu durumda 16 Şubat 1916'da Rus işgaline giren Erzurum'un 12 Mart 1918'de geri alındığı da düşünülürse şehrin iki yıldan fazla bir süre düşman idaresi altında kaldığına hükmedilebilir. Bu süre zarfında işlenen zulüm ve katliamlar ve savaş sırasında uygulanan tehcir de göz önüne alındığında Erzurum'un nüfus ve demografisinin haylice sarsıntı geçirmiş olduğu söylenebilir.

Birinci Dünya Savaşı sırasında Erzurum'un nüfus potansiyelini etkileyen bir diğer husus da şüphesiz Ermeni tedhiş hareketleri ve tehcirdir. Cihan harbi esnasında Osmanlı Devleti'nin aldığ 1 idari bir tedbir olarak değerlendirilebilecek tehcir uygulaması, devletin Ermeni ayaklanmasına karşı koymasının bir yöntemidir. Zira Rusya, İngiltere, Fransa ve İtalya ile savaşıldı̆̆ Ermenilerin bağımsızlık isteği ile ayaklanması, düşmanla iş birliği yapması, savaş zamanında vatana ihanet suçunu işlemesi, Müslüman halka karşı katliam yapması ve halkın da kendini korumak için mukabele etmesi zorunlu ve meşru bir tedbir olarak tehciri gündeme getirmişti

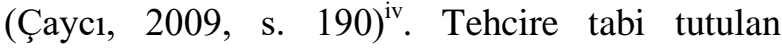
Ermenilerin sayısı hakkında yerli ve yabancı kaynaklar arasında büyük farklılıklar söz konusudur. 1914 yılı verilerine göre Erzurum'un toplam nüfusu 815.432 olup bunun 673.297'si Müslüman, 136.618'i de Ermeni'ydi. Mütebaki 4.864 kişi de Rum'du. Dâhiliye Nezareti'nden 23 May1s 1915'te Erzurum'a gönderilen şifrede vilayetin köy ve kasabalarındaki Ermenilerin Musul Vilayetine, Zor Sancağı'na ve Urfa'da hükümetin göstereceği yerlere gönderilmesi istenmişti. Nezaretin dört gün sonraki bir yazısında da Rus sinırında olması nedeniyle Erzurum'daki bütün Ermenilerin tehcire tabi tutulması direktifi gönderilmişti. Erzurum Ermenilerinin tehcirine ise başta merkeze bağlı ova köyleri olmak üzere 1915 yılı Haziran ayı başlarında girişilmişti (Demirel, 1996, ss. 49-65). Erzurum'daki nüfus hareketlilikleri ileride ele alınacak olup şurası ilave edilmelidir ki; tehcirden dolayı Osmanlı ülkesindeki toplam nüfusları 1.300.000 civarında olan Ermenilerin 702.900 kadarı göç ettirilmiştir. Ermenilerin I. Dünya Savaş1 içindeki toplam kayıpları ise 300.000'i geçmemektedir (Uçarol, 2000, s. 492) ${ }^{\mathrm{v}}$.

Rusların tarihi şark siyaseti çerçevesinde Doğu Anadolu'daki Türk-Müslüman varlığına karşı tampon olarak kullanılabilecek taşeron bir ulusal varlık hiç şüphesiz Ermenilerdi. Uzun yıllardan beri buradaki Ermenilerle yakından ilgilenen Ruslar bu vesile ile bölgede kendilerine ait bir etki alanı oluşturma gayreti içine girerek İskenderun Körfezi'ne çıkacak bir yol açmak niyetinde idiler (Kryblis, 2001, ss. 2-6). ${ }^{\text {vi }}$ Bu ilginin bir neticesi olarak Ermeniler 1916 Şubat'ında Erzurum'a giren Ruslara öncülük etmiş ve şehrin muhtelif yerlerindeki cephaneler infilak ettirilmişti. Erzurum halkının silahları ellerinden alınmış, direnişe öncülük edebilecek önemli isimler de ya tutuklanmış veya öldürülmüştü. $\mathrm{Bu}$ şekilde savunmasız birakılan Erzurum'da silah arama bahanesiyle evlere giren istilacilar ahalinin y1llardır biriktirdiği mücevherat, para vesairesine de el koyarak halk1 iyice zor bir durumda bırakmışt1 (Som, 2005, s.102). Ermenilerin Ruslarla bu şekilde yakınlaşması ilerleyen 
dönemde meyvesini vermiş ve ihtilalden sonra çekilmeye karar veren Ruslar Ermenileri askeri ve idari anlamda teşkilatlandırmışlardı. Bilhassa 2 Mart 1918'de Erzurum'a gelerek tüm Rus subaylarını emri altında toplayan Antranik Ozanyan Erzurum Merkez Komutanlığg'nı da uhdesine alarak geniş çaplı bir katliama girişmişti (Demirel, 1996, s.84) $)^{\mathrm{vii}}$. Erzurum Garnizon komutanlığına ise Bulgar uyruklu bir Ermeni olan Albay Torkom atanmıştı (Serţelik, 2015, s. 262). Erzurum katliamını tertip eden Antranik'e karş1 yer yer direnişler vuku bulmuştu. Mehmet Nusret'in ifadesiyle Haydari Boğazı, Evrenni, Tazegül, Tortum ve Narman'da icra edilen direnişler şükran ve takdir ile yâd olunacak türdendir. Bu katliam ve mukavemette ise yaklaşı 25.000 Erzurumlunun öldüğü tahmin edilmiştir (Som, 2005, s.105) $)^{\text {viii }}$.

Ermeni katliamlarına karşı Bakü İslam Cemiyet-i Hayriyesi, Oltu Milli İslam Komitesi (Haşimoğlu, 1959, s.20) ve İspir Direniş Cemiyeti gibi teşkilatlar Müslüman ahaliyi muhafaza ve müdafaa etmeye çalışmışlar ise de Erzurum'un düşman işgalinden kurtuluşu ve çeteci Ermenilerin şehirden tamamen çıkarılması, Albay Kazım Karabekir komutasındaki Osmanlı ordusunun görev aldığı ileri harekât neticesinde mümkün olmuştur (12 Mart 1918). Şehir bu şekilde kurtarılmış ise de Ermenilerin kaçmadan önce Erzurum'da yaptığı tahribat da hayli korkunç olmuştur. Erzurum'u terk etmeden önce çeşitli mahallelerden 3.845 kadın ve erkeği öldüren Ermeniler Müslüman ahalinin 14.767.344 kuruş değerinde kıymetli mallarını gasp etmiş ve son olarak da çevre köylerden şehre göç etmekte olan 4.644 kişiyi şehit etmişti. Şehir kurtarıldıktan sonra ortada olan cenazelerin definleri dahi 52 saat sürmüştü. İçlerinde Hükümet Konağı ile kolordu karargâhı olarak kullanılan bina da dâhil olmak üzere pek çok yapı keza Ermeniler tarafından son kertede ateşe verilmiş ve tamamen yakılmıştı (Küçükuğurlu, 2008, s. 270,271).

Savaş sonrasında Erzurum'da yapılan tespitlere göre posta işlemleri düzensiz bir hale gelmiş, yerli tüccar nakliye konusunda hayli sıkıntı yaşamış, ahali dünyadan habersiz, içtimai vaziyet karanlık altındayd. Diğer taraftan tuzlalarda Duyun-1
Umumiye memurları madeni para dışında bir ödeme aracı kabul etmemekte, bu da nakit paranın kıymetini düşürmekteydi. Az yıpranmış kâğıt paranın hükümet daireleri, Ziraat Bankası, posta veya maliyece kabul edilmemesi halkın mali müzayakasını artırıyordu. Okullar açılamamakta, vakıfların kontrolündeki cami, çeşme vesairenin bakımı yapılamamakta, gelirler yerli yerince tasarruf edilememekte, hükümetçe gönderilmesi vaat edilen tohumluğun beşte birinin ancak gönderilmiş olmasından dolayı halk iyice zorluk çekmekteydi. Oldukça zor durumda bulunan 2.000 kişinin günlük ihtiyaçları 15 gün süreyle Hilal-i Ahmer Cemiyeti karşılamış ise de Cemiyet'in geri dönmesinden dolayı bunların bakımını belediye üstlenmiști. Belediyenin bu yükü daha fazla kaldıramayacağı anlaşıldığından bu kişilerin açlıktan ölümle yüz yüze kalmaları gibi bir tehlike belirmişti. İlgili resmi daireler kışlık yakacak sorununu çözemediğinden harap evlerin ahşap kısımları yakacak olarak kullanılmış, bunlar ise daha ziyade resmi dairelerin 1sınması için sarf edilmişti. Mahrukat müteahhitleri de ev kalıntılarının yakacak olarak kullanılmasına ses çıkarmadığı için şehrin yerleşim dokusu oldukça bozulmuştu (Başbakanlık Osmanlı Arşivi, Dâhiliye İdare-i Umumiye (BOA. DH. İ. UM.) 1910/1-23). ${ }^{\text {ix }}$

Ahmed Refik (Altınay) Kafkas Yollarında isimli eserinde, işgal altında bulunduğu yıllarda Erzurum'daki tabloyu şöyle özetlemiştir:

Erzurum bir harâbe gibi. Câmiler ambar vazifesi görmekle kurtulabilmiş. Mâmafîh bunların da müstesnâsı var. Lala Mustafa Paşa Camii, Mimar Sinan'1n bu güzîde eseri, bütün müzeyyenâtından mahrum. Pencerelerinin etrâfinı süsleyen zengin çiniler bile sökülmüş. Erzurum'un bu kısmı (yani şehrin yönetim birimlerinin ve en büyük konaklarının yer aldığı merkezi kısmı) kâmilen harap. Hükümet dairesi, mîrî emâkîn, dumandan simsiyah kesilmiş. Korkunç bir iskelet halinde, dört duvardan başka bir şey değil. Kilise Meydanı civarı, İslam mahalleleri yıkılmış ve yakılmış. (Yenikap1 semtindeki şimdiki Şair Nefi Ortaokulu olan) idâdî mektebi tiyatroya tahvîl edilmiş. Çarsı içlerinde Ruslardan kalma 
üzerinde Rusça yazılar, sinema mahalleri var... Ahali henüz yerlerine avdet etmemiş. Mevcut nüfus ancak on bin kişiyi tecâvüz edebiliyor. Erzurum Ruslar tarafindan mühim bir üssü'1 harekât (hareket merkezi) ittihâz edilmiş. Şehre pek çok emtiâ getirilmiş. Rus zâbitleri aileleriyle Erzurum'a yerleşmişler. Eğlenceler, tiyatrolar, sinemalar, hiçbir şey eksik değil. Rusların çekilmesi üzerine şehir kâmilen Ermenilerin elinde kalmış. İste bütün zulümler, yangınlar ve facialar o zaman başlamış. Erzurum sokaklarından toplanan İslam naâş1 dört bini mütecâviz... Erzurum'da yakılan binalar hesapsız. Martın dokuzunda çekilen Ermeniler hemen her tarafi yakmışlar, yıkmışlar, icâb ettiği zaman da müdâfaa etmişler. Taş mağazalar üzerindeki mermi yaraları bu müdafaanın son eserleri. Daha ziyâde müdâfaada bulunamayacaklarını anladıkları zaman, peşlerinde ölüm ve ateşten mürekkep bir harâbe bırakarak kaçmışlar. Feci intikâm... (Küçükuğurlu, 2008, s. 272) ${ }^{\mathrm{x}}$; Arşiv Belgeleriyle Ermeni Faaliyetleri (ABEF)/2, s.228).

\section{Cihan Harbinde Erzurum'da Nüfus Hareketlilikleri}

XX. yüzyılın başlarında Osmanlı ülkesinde ilki 1903 yılında başlayıp 1906 yılında tamamlanan, ikincisi de 1914 yılında yapılan iki nüfus sayımı mevcuttur (Sungur, 1999, s. 564). 1914 y1lına ait nüfus istatistiklerinde Erzurum Vilayetinde bulunan milletlerin nüfusu aşağıdaki tabloda gösterilmiştir.

Tablo 1.

1914 sayımına göre Erzurum 'unnNüfusu (Karpat, 2003, s. 209)

\begin{tabular}{llcccccccc}
\hline Müslüman & Ermeni & $\begin{array}{c}\text { Ermeni } \\
\text { Katolik }\end{array}$ & Rum & Protestan & Yezidi & Süryani & Çingene & Keldani & Yahudi vd. \\
\hline 673.297 & 125.657 & 8.720 & 4.859 & 2.241 & 517 & 88 & 24 & 13 & 16 \\
\hline
\end{tabular}

Toplam: 815.432

O yıllardaki Erzurum Vilayetinin mülki taksimatı Erzurum, Erzincan ve Bayezid Sancaklarından oluşmaktaydı. Erzurum Merkez Sancă̆ı'nda aynı istatistiklere göre toplam 118.777 kişi bulunmakta olup bunun 83.070'i Müslüman, 32.751'i Ermeni olup mütebakisini yukarıda adi geçen milletler oluşturmaktaydı (Karpat, 2003, s. 209; BOA. DH. SN. THR. 82/55). ${ }^{\mathrm{xi}} \mathrm{Bu}$ hesaba göre Ermeniler vilayet genelinde toplam Müslüman nüfusun \%20'si civarında iken Erzurum Merkez sancağında ise $\% 40$ ' 1 nispetindeydi.

Savaşın ilk yılında durum böyle iken işgal ve istila yıllarında pek çok açıdan harap olan şehirde nüfus ve tapu gibi resmi kayıtların da büyük oranda zayi olduğu anlaşılmaktadır (BOA, DH. SN. THR, 2/28; 80/29; 82/33; 82/55; DH. İ. UM. 20-18/1270). 14 Nisan 1918 tarihinde Dâhiliye Nezareti'nden Trabzon, Erzurum, Bitlis, Muş,
Mamuretülaziz, Beyrut ve Suriye Vilayetleri ile Kudüs Mutasarrıflığ 1 ve Van Valisi'ne gönderilen bir telgrafla, savaş sırasında hangi kazaların nüfus sicillerinin kurtarıldığı ve hangilerinin zayi olduğunun acilen bildirilmesi istenmişti (BOA. DH. ŞFR. 86/120). ${ }^{\text {xii }} 14$ Mayıs 1918'de Erzurum'dan Dâhiliye Nezareti'ne gönderilen cevapta da nüfus kayitlarının tamamen yok olduğu, pek çok nüfusun da telef olduğu ifade edilerek yeniden bir sayıma ihtiyaç duyulduğu belirtilmişti. Bunun için de becerikli bir nüfus müdürüyle 5.000 adet sicil müsvedde defteri, 200.000 adet ücretli, 100.000 adet de ücretsiz nüfus tezkiresi istenmişti. 4 Mart 1920 tarihinde Dâhiliye ve Harbiye Nezaretleri arasında cereyan eden yazışmalarda Erzurum ve Trabzon'un çoğu bölgelerinin istilaya uğramasından dolayı nüfus ve asker alma şubelerinin kayıtlarının zayi olduğundan bahsedilerek 1315, 1316 ve 1317 
(1901, 1902 ve 1903) doğumluların askere alınmaları işlemlerinin aksadığı öne sürülmüştü. $\mathrm{Bu}$ aksaklığın giderilmesi için de tez elden bir nüfus sayımına ihtiyaç olduğu yazılarak bunun için gerekli tahsisatın bir an önce gönderilmesi lüzumu vurgulanmıştı (BOA. DH. SN. THR. 2/28). İşgalden kurtarılan vilayetlerin zaruri ihtiyaçlarının giderilmesi, ahalinin durumunun düzeltilmesi, gerekli inşaatların (yeni kurulacak köyler, meskenler ve kamu binaları gibi) acilen başlatılması için 1334/1918 senesi Maliye Nezareti bütçesine 5.000.000 liralık olağanüstü bir tahsisat ilave edilmesi kararı alınmıştı (BOA. DH. İ. UM. 20-18/12-78). Sicill-i Nüfus İdaresi'nce Erzurum, Van, Trabzon, Bitlis ve Musul gibi istilaya uğramış yerlerde yeniden bir nüfus sayımı yapılmak üzere Dâhiliye Nezareti bütçesine tahsis edilen bu beş milyon liralık tahsisattan yeterli miktarda pay ayrılması istenmişti (BOA. DH. SN. THR. 80/29). Ancak bir zaruret halini alan sayım meselesinin halledilemediğini belirtmek gerekir. Zira bu tarihlerden itibaren yapılan ilk sayım 1927 sayımidir.

Görüldüğü üzere harp ve işgal nedeniyle Erzurum'daki resmi kayıtlar imha edilmiştir. Bu sebeple vilayetin ve bağlı birimlerin nüfus hareketliliklerini ortaya çıkarmak için vilayetle Dâhiliye Nezareti arasında savaş sırasında ve sonrasında bu husus hakkında ziyadesiyle önem kazanan yazışmalara odaklanmak yerinde olacaktır. Zira savaş esnasında ve müteakip aylarda işgal edilen yerlerin mevcut nüfus durumları ve Ermenilerin meskûn olduğu yerleşim birimlerinin acilen bildirilmesi yönünde vilayetlerden sürekli bilgi talebinde bulunulmuştur (BOA. DH. ŞFR. 92/54). Bir diğer husus da yapılmas1 muhtemel bir sulh kongresinde söz konusu olması durumunda nüfusun savaştan önceki ve sonraki durumunun bilinmesi gibi bir ihtiyacın ortaya çıktığıdır. Bu nedenle Erzurum, Trabzon, Bitlis, Van ve Erzincan'a gönderilen şifrelerde harpten önceki kayıtlı nüfus, mevcut nüfus, mülteci say1s1, geri dönen ve dönmesi muhtemel olanların yaklaşık sayısı ve aradaki kayıp ve ölü oranlarının en doğruya yakın tahminlerle ifade edilmesi istenmiştir (BOA. DH. ŞFR. 94/204). 22 Aralık 1918 tarihli bu istek 21
Ocak 1919'da yinelenmiştir (BOA. DH. ŞFR. 95/191). Erzurum Valisi Münir Bey bu isteklere 22 Ocak'ta yazdığı cevapta kayıtlı ve mevcut nüfus ve teferruatıyla bizzat ilgilendiğini, vilayetin büyük bölümünden cevap alındığını, yalnız telgraf iletişimi tam olarak tamamlanmayan Bayezid Sancağı'ndan sıhatli bilgi alınamadığını ve buraya özel süvari göndererek işi halletmeye çalıştığını belirtmiştir (BOA. DH. ŞFR. 611/69). 7 Kasım 1918'den itibaren elde ettiği bilgileri Sicilli Nüfus İdare-i Umumiyesi'ne ileten Vali Münir Bey Bayezid ile ilgili tespitlerini başarıyla tamamladıktan sonra burayla ilgili sayım sonuçlarını da iletmiştir. Bu sonuçlar aşağıda ifade edilmiştir. Elde edilen bilgilere göre nüfusun sayısı ile ilgili tespitler sunulacaktır. Nüfusa ilişkin olarak valinin elde ettiği ve aşağıda madde madde verilen rakamların 1329/1914 y1lındaki sayımın sonuçları olduğu ve valinin kimi yerlerden yeterli ölçüde bilgi alamadığı hatırda tutulmalıdir.

- Erzurum Merkez'e bağlı Kiğı Kazasında 15.000 Türk, 4.000 Ermeni, 15-20.000 Kürt ve 150 de Protestan bulunmakta olup Arap, Keldani, Ortodoks veya Katolik kimse bulunmamaktadır (BOA. DH. SN. THR. 82/55). Bayburt'ta 60.715 Müslüman, 9.872 Ermeni, 1.250 Rum bulunmaktadır. Yusufeli'de 31.600 Türk, 1.720 Ermeni Katolik, 178 Ermeni Ortodoks ve 25 Rum mevcuttur. İspir'de ise 30.000 nüfusun 1.500 'ü Ermeni olup geri kalanların hepsi Türk'tür. Kazada başka unsur bulunmamaktadır (BOA. DH. SN. THR. 82/55). Amerikan konsolosluk raporlarına göre şehir merkezinde 60.000 70.000 Müslümana karşılık Ermeni sayısı 20.000 kadard1 (Sakin, 2014, s. 209).

- Erzincan kazasında 3.370 Türk, 6.669 Kürt, 4.000 Ermeni, 104 Rum, 201 Protestan, 24 Süryani; Refahiye kazasında 17.430 Türk, 6.390 Kürt, 450 Ermeni, 1.779 Rum; Kemah kazasında 17.100 Türk, 3.400 Kürt, 2.500 Ermeni, 560 Rum, 100 Protestan; Kuruçay kazasında 9.070 Türk, 2.650 Kürt, 70 Ermeni; Pülümür kazasında 200 Türk, 10.000 Kürt 
ve 90 Ermeni nüfus tahmin edilmektedir

(BOA. DH. SN. THR. 82/55). Toparlanacak olursa Erzincan'da 47.170 Türk, 29.109 Kürt, 7.110 Ermeni ve 2.768 Rum ve Protestan olmak üzere toplam 86.157 kişi bulunmaktaydı.

- Bayezid Sancağı'nın nüfusu ile ilgili kayıtlara bakıldığında; Bayezid Merkez Kazasinda 1.500 Türk, 3.500 Kürt, 2.100 Ermeni olmak üzere toplam 7.100 kişi bulunmaktadır. Diyadin'de 7.330 Kürt, 130 Türk olup Arap veya Ermeni bulunmamaktadır. Tutak'ta 5.000 Türk ve 3.200 Kürt olup 300 nüfustan ibaret olan Ermeniler istila sırasında Rusya'ya göç etmişlerdir. Tutak'ta başka unsurlardan kimse bulunmamaktadır (BOA. DH. SN. THR. 82/55). Karakilise Kazasinda 15.000 Kürt, 15 Türk ve 3.000 de Ermeni bulunmaktadır. Eleşkirt'te keza 15.000 Kürt, 7.000 Türk ve 2.000 Ermeni ile 1.000 civarında da Katolik vardır (BOA. DH. SN. THR. 82/55). ${ }^{\text {xiii }}$. Buna göre Bayezid Sancağı'nda tespit edilebildiği kadarıla toplam 13.645 Türk, 44.030 Kürt, 7.100 Ermeni ve 1.000 de Katolik olmak üzere toplam $\mathbf{6 5 . 7 7 5}$ kişi bulunmaktadir.

- Erzurum Valisi Münir Bey'in 1 Şubat 1919 tarihli telgrafinda ise vilayetin savaş öncesi kayıtlı nüfusunun 704.573 olduğu, vilayete iltica edenlerin 448.607, geri dönen mültecilerin 173.304, geri dönme ihtimali olanların 108.098, zayi ve kayıpların da 207.105 kişiden ibaret olduğu belirtilmiştir (BOA. DH. SN. THR. 82/55). Valinin burada savaş öncesi nüfus yekûnu olarak verdiği 704.573 rakamı ile yukarıda Karpat'tan alınan 815.432 rakamı arasındaki farkın Bayezid Sancağ1 nüfusunun tam olarak tespit edilememiş olmasından kaynaklandığ düşünülmektedir. Karpat'ın kullandığı istatistiğe göre Bayezid Sancağı'nda toplam 123.906 kişi gösterilmiştir.
Erzurum Valisi Tahsin Paşa'nın 7 Haziran 1916 tarihli bir şifresine göre askeri gerekliliklerden dolayı Erzurum'da tahliye edilmesi lüzumu görülen arazinin nüfusunun yaklaşık 400.000 civarında olması bu vilayetteki nüfus hareketliliğinin boyutunu göstermesi açısından önemlidir (BOA. DH. ŞFR. 522/67). 1 Şubat 1919'da bölgede yapılan incelemelerde sadece Erzurum'dan 448.607 Müslümanın göç ettiği tespit edilmiştir. $\mathrm{Bu}$ da savaş öncesi Müslüman nüfusunun yarısından fazlasının göçe maruz kaldığını gösterir (Yüksel, 2008, s. 267) ${ }^{\text {xiv }}$. Yine bir başka tespitte resmi kayıtlara göre Erzurum'dan 5.500 Ermeni'nin tehcire tabi tutulduğu ortaya konmuştur (Halaçoğlu, 2014, s.95) ${ }^{\mathrm{xv}}$. Bu sayı Erzurum şehrinden belli bir dönemde göçürülen Ermenilere ait olmalıdır. Bağlı kaza ve sancaklardan göçürülenlerin de bu sayıya dâhil olmadığı söylenebilir (Çiçek, 2005, s.248). Çünkü Genelkurmay Başkanlığı'nın yayınladığı belgelerde Erzurum Vilayetinde kay1tl1 128.657 Ermeni nüfustan (ki bunun 91.514'ü Erzurum'da, 25.171'i Erzincan'da, 11.972 'si ise Bayezid'de idi) 120.000 'i sevke tabi tutularak Elâzığ yoluyla Musul ve Zor'a nakledilirken kalanlar ise "kısmen çarpışmalarda ölmüş veya kaçmış" kategorisinde belirtilmişti $(\mathrm{ABEF} / 1, \quad \mathrm{~s} .147-149)^{\mathrm{xvi}}$. Genelkurmay'in Erzurum'dan 120.000 Ermeni'nin tehcir edildiği yönündeki kaydına da keza ihtiyatlı yaklaşmak gerekir. Zira Ermeni yanlısı Fransız yazar Barbi, 1914-1915 kışında yani henüz tehcir kararı alınmadan evvel Erzurumlu 100.000'den fazla Ermeni'nin Kafkasya'ya göç ettiğini belirtmiştir. Aynı kaynağa göre binlerce Erzurum Ermeni'si ise Dersim Kürtlerine ve Mama Hatun Kızılbaşlarına sığınmak suretiyle tehcirden kurtulmuştur (akt. Sertçelik, 2015, s.332). Yine McCarthy (2012), 1890'lardan itibaren başlayan devrimci Ermeni çete faaliyetlerinden ve Rusların cazip tekliflerinden dolayı çok sayıda Ermeni'nin, iktisadi gereklilikler ve güvenlik şartlarının da zorlamasıyla, yerini yurdunu terk ederek Rusya'ya gittiğini tarihsel süreçle birlikte ele almıştır (s. 133-136). $\mathrm{Bu}$ verilerden hareketle sayılar hakkında yerli ve yabancı kaynaklar arasında tenakuzlar olduğu belirtilmelidir. 
Rus istilasının başladığı günlerden itibaren

Osmanlı ülkesinde güvenli gördükleri alanlara iltica eden Erzurumluların sayısı oldukça kabarıktı. Bu iltica ve muhacerete hazırlıksız yakalanan İttihad ve Terakki yönetiminin aldığı tüm önlemlere rağmen organizasyon, sevk ve idarede çok da başarılı olduğu söylenemez. Başta Sivas, Adana, Halep ve Aydın olmak üzere ülkenin farklı coğrafyalarına sığınan Erzurumluların biraz olsun umutla geldikleri yeni memleketlerde bu duygu, yerini bıkkınlığa bırakıyordu. Tasvir-i Efkâr 1919'da yayınladığ1 bir istatistikte Erzurum'dan iltica edenlerin sayısını 448.277 olarak vermiş, 1920 yılına ait resmi bir istatistikte ise Erzurum mültecileri 287.474 kişi olarak belirtilmişti (Ballı, 2015, s.878). Bu külliyetli rakamların yanında İzmit'e iltica eden 6 Erzurumlu (BOA. DH. ŞFR. 576/67), Kayseri'ye gidip de Erzurum'a geri dönmek isteyen 8 ailede 21 nüfus Rum ve Ermeni (BOA. DH. ŞFR. 601/61), 1919'da Erzurum'a geri dönen 177 Ermeni ve Ermeni mühtedi (BOA. DH. ŞFR. 624/139) ${ }^{\text {xii }}$, Maraş'a giden Erzurum ve Bitlis Çerkezlerinden 182 hanede 768 kişi (BOA. DH. ŞFR. 629/67) gibi infiradi nüfus hareketlilikleri de tespit edilmiştir. Esasında savaş ve istila şartları göz önünde bulundurulduğunda Doğu Anadolu'daki iç göçler hakkında sağlıklı kayıtlar tutulamamış olması ve böyle bir ortamda sayım yapmanın imkânsızlığı anlaşılabilir. McCarthy'nin (2012), 1916 y1lına ait Dâhiliye Nezareti kayıtlarına dayandırdığı tespitlerine göre savaş sirasinda Erzurum'dan sadece Sivas'a 300.000'den fazla kişi iltica etmişti. Yine Erzurum'un doğusu ile Trabzon'dan Samsun'a 79.100, Erzurum'un doğu ve güneyi ile Van'dan Mamuretülaziz'e 80.000 kişi gitmişti. Bu sayıların tahmini olduğu, kayıt dışı pek çok mülteci olduğu ve rakamlarda savaş sonuna kadar pek çok değişiklikler meydana gelmiş olabileceği dikkatten uzak tutulmamalıdır (s.257).

Ermeniler de dâhil olmak üzere Erzurum'u terk eden ahalinin bir kısmı geri dönmek istemiş ve devletçe dönüşleri düzenleyen alt yapı kurulmuş (Çelik, 2008, ss.143-163) ise de aşağıdaki rakamlar göz önüne alındığında önemli bir kısmının geri dönmediği sonucuna ulaşı1ır.
Erzurum vilayetinin savaş sonrası genel nüfusu Vali Reşid Bey'in Dâhiliye Nezareti'ne 1919 yılının sonlarına doğru gönderdiği yazılarda ifade edilmiştir. Doğruya en yakın rakamları verdiğini ifade eden vali, 1919 yılı Ekim ayında nüfusu 410.000 olarak belirtmişken aynı yılın Aralık ayında mevcut nüfus defterlerine göre vilayet genel nüfusunun 415.399 olduğunu ve bunun sadece 500'ünün gayrimüslim nüfus olduğunu bildirmiştir (BOA. DH. İ. UM. 19-10/1-6; BOA. DH. ŞFR. 649/48; 654/43) ${ }^{\text {xviii }}$. Görüldüğü üzere vilayet genelinde gayrimüslim nüfus yok denecek kadar az kalmıştı. Bu hususu teyit eden 13 Aralık 1919 tarihli bir başka kayıtta Bayezid Sancağında Hristiyan unsurlardan kimse olmadığı, Türk ve Kürtlerin harici düşmana karşı yekvücut olarak hareket ettiği, ahalide hükümet ve saltanata karşı hiçbir muhalefet fikri bulunmadığı belirtilmiştir (BOA. DH. İ. UM. 11-6/9-67) ${ }^{\text {xix }}$. Bu kayitlardan hareketle savaştan önce toplam nüfusu 815.432 kişi olan Erzurum'da savaştan sonra 415.399 kişi kalmıştır denilebilir. Aradaki farkın 136.618'inin (yahut Genelkurmay belgelerine göre 128.657'sinin) Ermeni olduğu ve bunların da tehcire veya vilayeti terke maruz kaldığ 1 düşünüldüğünde $\quad 260.000-270.000$ kişilik bir Müslüman nüfus kaybı olduğu ortaya çıkar. I. Dünya Savaşı'ndan sonra sağlıklı bir nüfus sayımı yapılamamıştır. 1927 sayımına göre Erzurum'da $\% 0,1$ nispetinde gayrimüslim nüfus bulunmaktadır (Behar, 2003, s.64). Bu durum savaş sonrasında Erzurum'da neredeyse gayrimüslim nüfus kalmamıştır yönünde yukarıda ortaya konan iddiay1 teyit etmektedir.

I. Dünya Savaşı sırasında Erzurum Vilayetinin birer sancağ1 olan ve Cumhuriyet döneminde vilayet statüsüne kavuşturulan Erzincan ile Bayezid Erzurum'la birlikte düşünüldüğünde 1927 y1lı nüfus sayımına göre üç vilayetin toplamı 507.802 rakamına ulaşır.1927 yılı sayımında elde edilen rakamlardaki eksiklikler 1928 y1lında güncellenmiş ise de burada bahse konu üç vilayetin yekûnlarında önemli denebilecek bir değişiklik yapılmamıştır. Bu sayımda elde edilen rakamlara göre Erzurum, 137.469 kadın, 133.456 erkek olmak üzere toplam 270.925 nüfus ihtiva etmekteydi. Erzincan Vilayetinde 69.128 kadın ve 
65.315 erkek olmak üzere toplam 134.443; Bayezid Vilayetinde ise 46.700 kadın, 55.734 erkek olmak üzere toplam 102. 434 nüfus bulunmaktaydı (Türkiye Nüfusu, 1927, ss.15-20). Erzurum Vilayetinin Osmanlı dönemindeki mülki taksimatı ile Cumhuriyetin ilk yıllarındaki taksimat arasında farklar olduğu unutulmamalıdır. Öyle ki Cumhuriyet'in ilk yıllarında Yusufeli'nin (26.392 nüfus) Artvin'e, Bayburt'un (48.842 nüfus) Gümüşhane'ye ve Iğdır ve Kulp ilçelerinin (35.502 nüfus) de Bayezid'e bağlı olduğu belirtilmelidir. $\mathrm{Bu}$ durumda da Osmanl1 dönemindeki mülki idare Cumhuriyet döneminde devam ediyor olsa idi Erzurum vilayetinin nüfusu 1919-1927 yılları arasında 132.135 kişi artmıştır denilebilirdi.

\section{Sonuç}

Birinci Dünya Savaşı'nın en yıkıcı etkilerine maruz kalmış olan Erzurum Vilayeti ve Erzurum şehri savaştan bütünüyle harap bir halde çıkmıştır. Yaklaşık iki yıl süren Rus işgali ve Rusların çekilmesiyle onların yerini alan Ermeni çeteleri Erzurum'un tarihî ve medenî birikimini yok etmenin yanı sıra nüfus ve demografisini de büyük ölçüde değiştirmiştir. Vilayete bağlı birimlerde girişilen katliamlarda Müslüman nüfus zarar görürken savaş sırasında uygulanan tehcirde Ermeniler neredeyse tamamen vilayeti terk etmiştir. Esasında Ermenilerin uyguladığı vahşetin boyutlarına bakıldığında tehcirin ne derece insani ve zaruri bir tedbir olduğu tereddütsüz kabul edilir.

İşgal ve istilanın yıkıcı etkilerinden biri de şüphesiz tarihçiler için çok önemli olan resmi kayıtlar üzerinde olanıdır. Zira kamu binalarının tahrip edilmesi, yakılması veya başka suretlere tahvil edilmesi nedenleriyle içlerindeki kayıtlar da yok olma tehlikesiyle yüz yüze kalmıştır. Bu nedenle vilayetin ve bağlı birimlerinin o dönemdeki nüfusu ve demografik yapısı tam anlamıyla tespit edilememekte, savaştan dolayı kaç kişinin göç ettiği, öldüğü veya kayıp olduğu bilinememektedir. Bu açmazdan bir nebze de olsa kurtulabilmek için elde edilen belgelerde nüfusla ilgili olarak verilen her kayıt üzerinde önemle durulmuştur. "Tarihi hadiselerin demografik sahalarda mutlaka akis ve neticelerinin olduğu ve demografik amillerin hesaba katılmamasının birçok hadisenin ilmi izahlardan mahrum kalmasına yol açtığı" gerçeğinden hareketle elde edilen vesikalar ışığında Erzurum'un savaş öncesi ve sonrası yerleşme ve nüfus kayıtları incelemeye tabi tutulmuştur. Buna göre vilayetin nüfusu yarı yarıya azalmış, gayrimüslim nüfus yok denecek bir seviyeye inmiştir. Savaşın zor koşullarında köylerin boşaltılması ve evlerin özellikle de yakacak için tahrip edilmesi şehir yapılanmasını baştan sona olumsuz etkilemiştir. Nüfus değişikliklerinin tüccar, işçi, esnaf, çiftçi, memur vs. üzerindeki tesirleri de göz önüne alındığında vilayetteki işgücü kaybının ve buna bağlı olarak da mali-iktisadi yapının temelden sarsıldığ 1 neticelerine ulaşılabilir.

\section{Kaynakça}

Ahmad, F. (1985). İttihat ve Terakki'nin Dış Politikası, Tanzimat'tan Cumhuriyet'e Türkiye Ansiklopedisi (TCTA), İstanbul: İletişim Yayınları, C.2, ss. 298-301.

Aktar, A., ve Kırmızı, A. (2013). Diyarbekir 1915, Diyarbakır Tebliğleri (Diyarbakır ve Çevresi Toplumsal ve Ekonomik Tarihi Konferansi), İstanbul: Hrant Dink Vakfi Yayınları, ss. 289-323.

Altıntaş, A. (t.y.). Osmanlı İmparatorluğu'nun Tehcir Kararı Almas1 ve Uygulamas1, www.aku.edu.tr/aku/dosyayonetimi/ sosyalbilens/dergi/vii1/altintas.pdf s. 92. ET. 28.07.2015.

Arşiv belgeleriyle Ermeni faaliyetleri (2005). Ankara: Genelkurmay Başkanlığı Yayınları, C. 1-8.

Aydoğan, E. (2005). Ittihat ve Terakki'nin doğu politikast (1908-1918), İstanbul: Ötüken Yayınları.

Balcı, R. (t.y.). Tarihin Sarıkamış duruşması, İstanbul: Tarih Düşünce Kitapları.

Ballı, E. (2015). Birinci dünya savaşı yıllarında Erzurumlu mültecilerin iskân ve iaşesi, 100. Yılı Münasebetiyle I. Dünya Savaşı'nda Kafkas (Doğu) Cephesi Uluslararası Sempozyumu Bildirileri, Ankara: Atatürk Araştırma Merkezi Yayınlar1, ss. 857-897.

Başbakanlık Osmanlı Arşivi, Dâhiliye İdare-i Umumiye (DH. I. UM). Dosya Numarası $89-1 /$ Gömlek Numarası 1-3, 2018/12-70, 19-10/1-23, 20-18/12-78, 19-10/1-6, 11-6/9-67.

Başbakanlık Osmanlı Arşivi BOA, DH, Sicill-i Nüfus, Tahrirat (DH. SN. THR.), 2/28, 80/29, 82/33, 82/55.

Başbakanlık Osmanlı Arşivi. Dâhiliye Şifre Kalemi (DH. ŞFR), 86/120, 92/54, 94/204, 95/191, 611/69, 522/67, 576/67, 601/61, 624/139, 507/118, 629/67, 649/48, 654/43, 587/140. 
Bayur, Y. H. (1991). Türk Inkllabı Tarihi, Ankara: TTK Yayınları, Cilt III, Kısım III.

Beydilli, K. (2011). Tehcir, Türkiye Diyanet Vakfi İslam Ansiklopedisi (DIA), C. 40, s. 319-323. İstanbul: Diyanet Vakfi Yayınları.

Çaycı, S. (2009). Uluslararası hukuk açısından Ermeni sorunu ve 1915 olaylar1, Ermeni Sorunu Temel Bilgi ve Belgeler, (Der. Ömer Engin Lütem), Ankara: Terazi Yayıncılı, ss. 189-198.

Çelik, H. (2008). Ermeni tehciri ve tehcirden sonra dönen Ermenilerin iskân sorunu, Çă̆daş Türkiye Tarihi Araştırmaları Dergisi (ÇTTAD), 7(16-17), 143-163.

Çiçek, K. (2005). Ermenilerin Zorunlu Göçü (1915-1917), Ankara: TTK Yayınları.

Demirel, M. (1996). Birinci Dünya Harbinde Erzurum ve Çevresinde Ermeni Hareketleri (1914-1918), Ankara: Genelkurmay ATASE Yayınları,

Demirel, M. (2008). Doğu Anadolu'da idari yapılanma (1877-78 Osmanl1-Rus savaşı'ndan sonra), Atatürk Üniversitesi Türkiyat Araştırmaları Dergisi, Sayı 37, Erzurum, ss. 247-258.

Halaçoğlu, Y. Ermenilerin Suriye’ye Nakli: Sürgün Mü, Soykırım $M \imath$ ? , http://www.ttk.gov.tr/templates/resimler/ File/01.pdf, s. 14. ET. 02.08.2015.

Halaçoğlu, Y. (2014). Ermeni tehciri, İstanbul: BKY Yayınc1lk.

Haşimoğlu, M. (1959). Bakü İslam Cemiyet-i Hayriyesi ve Oltu Milli İslam Komitesi, Tarih Yolunda Erzurum, Erzurum, Y1l 1, Say1 4, ss. 20.

Karal, E. Z. (1999). Osmanlı tarihi, Ankara: TTK Yayınları, C. IX.

Karpat, K. (2003). Osmanl nüfusu (1830-1914), İstanbul: Tarih Vakfi Yurt Yayınları.

Kaya, F., ve Karataş, Y. (2014). Bayezid (Ağrı) vilayetinin sıhhi ve içtimai coğrafyası, Uluslararası Sosyal Araştırmalar Dergisi, 7(30), 158-180.

Krayblis, N. (2001). Rusya'nın şark siyaseti, (Yay. Haz. Mehmet Okur, Selçuk Ural), Erzurum: Aktif Yayınevi.

Kuran, E. (1992). Birinci dünya savaşı, DIA, C. 6, s. 196-200.

Kurat, A. N. (2014). Rusya tarihi-başlangıçtan 1917'ye kadar, Ankara: TTK Yayınları.

Küçükuğurlu, M. (2008). Erzurum belediyesi tarihi 1 , İstanbul: Dergâh Yayınları.
McCarthy, J. (2012). Ölüm ve sürgün-Osmanl Müslümanlarının etnik klyımı (1821-1922), (Çev: Fatma Sarıkaya), Ankara: TTK Yayınları.

Osmanl belgelerinde Ermenilerin sevk ve iskânı (18781920). Başbakanlık Devlet Arşivleri Genel Müdürlüğü Yayınları, Ankara 2007.

Osmanll imparatorluğu ve Türkiye'nin nüfusu 1500-1927 (2003). (Haz. Cem Behar), Ankara: Devlet İstatistik Enstitüsü Yayınları.

Özger, Y. (2006). Erzurum valisi Mehmed Emin (Yurdakul) Bey'in Erzurum vilayetinin ihtiyaçları ve gelişmesine ait layihas1, Atatürk Dergisi- Journal of Atatürk (Atatürk Üniversitesi Atatürk İlkeleri ve İnkılap Tarihi Enstitüsü Müdürlüğü), 5(2), 115-149.

Sakin, O. (2014). Ermeni isyanı günlüğü 1915, İstanbul: Yeditepe Yayınevi.

Saray, M. (2005). Principles of Turkish administration and their impact on the lives of non-muslim peoples: the Armenians as a case study, Ankara: Atatürk Araştırma Merkezi Yayınları.

Sertçelik, S. (2015). Rus ve Ermeni kaynakları ışı̆̆ında ermeni sorunu (1915-1923 sömürge savaşı), Ankara: SRT Yayınlar1.

Som M. N. (2005). Tarihçe-i Erzurum, (Yay. Haz. Ahmet Fidan), İstanbul: Erzurum Kitaplı̆̆ı.

Sungur, M. (1999). XIX. yüzyılda Osmanlı devletinde nüfus ve nüfus sayımları, Osmanl, Ankara: Yeni Türkiye Yayınları, C.4, ss. 558-566.

Uçarol, R. (2000). Siyasi tarih (1789-1999), İstanbul: Filiz Kitabevi,

Umumi nüfus tahriri, (28 Teşrinievvel 1927- Muvakkat Rakamlar), Ankara: Başvekâlet Merkezî İstatistik Müdüriyeti Umumiyesi Neşriyatı.

Ünal, L. (2015). Birinci dünya harbinde Erzurum'un düşmesi sonrası meydana gelen gelişmeler ile bölgede cereyan eden muharebelerin değerlendirilmesi, 100. Yll Münasebetiyle I. Dünya Savaşı'nda Kafkas (Doğu) Cephesi Uluslararası Sempozyuти Bildirileri, Ankara: Atatürk Araştırma Merkezi Yayınları, ss. 417-454.

Yıldırım, H. (2014). Mütareke yıllarında Osmanlı topraklarında göçleri önlemeye yönelik çabalar, Akademik Bakış, 7(14), 71-96.

Yüksel, M. (2008). I. dünya savaşında Erzurum'un ilk işgal günleri, Atatürk Üniversitesi Türkiyat Araştırmaları Dergisi, 37, 259-287. 


\section{Notlar}

i Kafkas cephesindeki askeri gelişmeler özetlenirken şu eserden faydalanılmıștır; Ramazan Balcı, Tarihin Sarıkamış Duruşması, İstanbul: Tarih Düşünce Kitapları. Harekâtın gün gün seyri için söz konusu esere müracaat edilebilir.

ii Hatta Erzurum'un düşmesi üzerine Rus Kafkas Orduları Başkumandanı Nicolas Nikolayeviç, Çar II. Nikola'ya gönderdiği bir telgrafta "Güçlü bir savunma şehri olan Erzurum'un ve 18 tabyasının firtına gibi bir taarruzla ve beş günlük sıcak çatışmalarla ele geçirildiğini” belirtmişti. Ona göre Erzurum'un ele geçirilmesi Trabzon, Tebriz ve Mezopotamya'ya ulaşma imkânı sağlayacak ve Kafkasya'da Rus askerî harekâtı etkisini artıracaktı. (Ünal, 2015, s. 429).

iii Örneğin 10.000 erkek nüfusu, 127 köy ve 5 nahiyeyi ihtiva eden Oltu'da Haziran 1918'de icra edilen halk oylamasında oy sahibi 5.279 kişi ittifakla Osmanlı tabiiyetini tercih etmiştir (BOA. DH. SFR. 587/140). Oltu 1877-78 Osmanl1Rus Savaşı'ndan sonra Rus hâkimiyetine girmiş ve Ruslar tarafından oluşturulan yeni idarede Kars'a bağlanmıştı. (Demirel, 2008, ss.247-258)

${ }^{\text {iv }}$ Ermenilerin bu ihanetlerinin yanında savaş sırasında yardım için 150 yataklı bir hastane açıp cephedeki Osmanlı askerlerine 15.000 pamuklu mintan hazırlayan Erzurum'daki bir kisım Ermenilerin hizmetlerini de anmak icap eder $(D H . \dot{I}$. UM. 89-1/1-3).

${ }^{v}$ Buradaki 702.900 (veya başka araştırmalarda geçtiği üzere ortalama 700.000) rakamı esasında Dâhiliye Nezareti'nden Sadaret'e gönderilen 7 Aralık 1916 tarihli bir rapordan alınmış olup Beydilli'ye göre Rus ve Ermeni birliklerinin önünden kaçarak yerlerini yurtlarını terk eden Müslümanların sayısını göstermektedir (Beydilli, s. 322). Beydilli'ye göre Kamuran Gürün bu sayıy hatalı olarak tehcire tabi tutulan Ermenilerin rakamı olarak vermiştir. (Gürün, 2010, s.321). Resmi kaynaklara dayanan kimi araştırmalar da keza 19151917 yılları arasında Doğu Anadolu'dan güneye tehcir edilen Ermenilerin sayısını 700.000 olarak vermişlerdir. (Saray, 2005, s. 43), Halaçoğlu ise yine resmi kayitlardan hareketle tehcir kapsamında olan Ermenilerin sayısının 450.000 civarında olduğunu belirtip Kafkasya ve İran'da göçe tabi tutulanlarla birlikte sayının 700.000'i bulduğunu kaydetmiştir. (Halaçoğlu, s.14).

vi Ancak daha geniş açıdan bakıldığında Rusların Ermeni politikalarının zaman ve şartlar muvacehesinde değişebildiği de bir gerçektir. Öyle ki Rusların Ermenileri himaye politikası savaş sırasında bir ara "Ermenisiz Ermenistan" seviyesine inmiş ve Ruslar Doğu Anadolu'da Ermenilerin boşalttığ1 yerlere Don ve Kuban Kazaklarını yerleştirmeyi dahi planlamışlardır. (Bayur, 1991, ss. 30-34).

vii Söz konusu katliamın ve Ermeni vahşetinin teferruatına burada girilmeyecek ise de numune olması açısından bkz. Demirel, age, s. 99. Yüz kızartıcı Ermeni vahșeti Rus Subaylarının dahi nefretini çekmiştir (ABEF, 2005, s. 85).

viii Mehmet Nusret'in direniş için verdiği yerlere ilave olarak Aşkale, Çat, İspir, Oltu ve Olur'u da saymak icap eder. (Demirel, 1996, ss. 121-141).

${ }^{\text {ix }}$ Erzurum Valisi Mehmed Emin Bey (Yurdakul)'in savaş öncesinde kaleme aldığı ve vilayetin genel durumu, sosyoekonomisi, yolları, üretimi, ithalat ve ihracat kapasitesi, ihtiyaçları ve gelişmesine ait raporlar için bkz. Özger, 2006 ss.115-149. x Bu kayıtları destekleyen 21 Mart 1918 tarihli askeri yazışmalara göre Erzurum şehrinde en fazla 30.000 kişi kalmıştı (ABEF, C. 2, s. 228).

xi Buradaki rakamlar Erzurum Valisinin Erzurum Nüfus Müdürü'nden aldığını ifade ettiği ve savaş öncesi rakamları gösteren cetveldeki bilgilerle örtüşmektedir. (BOA. DH. SN. THR. 82/55)

xii İttihat ve Terakki yönetiminin doğu vilayetleri politikası kapsamında, savaşın başlamasıyla birlikte, bölgede, yetkileri genişletilmiş, tecrübeli, parti politikaları ve devlet nüfuzunu etkin k1lacak, koordinasyon yeteneği olan valiler görevlendirme konusunda hassas davrandığ 1 anlaşılmaktadır. (Aydoğan, 2005, ss. 55-64).

xiii Dikkat edilirse Bayezid Sancağı ile ilgili olarak verilen rakamlar genel itibariyle yuvarlak rakamlardır. Bunda bölge ile olan haberleşme imkânlarının kısıtlı olması, bölgenin konargöçer aşiretlerden oluşması ve bunlardan dolayı sağlıklı bir sayımın gerçekleştirilememesinin etkili olduğu düşünülmektedir. Zaten Karpat'in Bayezid Sancağı ile ilgili olarak verdiği rakamlarla burada ortaya konan tahmini sayılar birbirini tutmamaktadır. 1925 yılında vilayet haline gelmiş olan Bayezid'in nüfusunun bu tarihte dahi tam olarak tespit edilememiş olduğu gerçeğinden hareketle savaş sonrasında yapılan yukarıdaki tahminlerin yeterli olacağ düşünülmektedir. Bayezid Vilayetinin 1925 y1lı sıhhi içtimai raporu için bkz. Kaya, Karataş, 2014, ss. 158-180.

xiv 1919 yılı nüfus tespitleri açısından da önemli bir yıldı. Zira bu dönemde mevcut Müslüman nüfusunun bölgeyi terk etmemesine ve bu coğrafyayı Ermenilere bırakmamasına dair Vilayat-1 Şarkiye Müdafaa-i Hukuk Cemiyetinin önleyici çalışmaları sürmekteydi. Erzurum Kongresi'nde de (1919) Heyet-i Temsili kararı olmadan göç edilmesinin yasak olduğu kararı alınmıştı (Yıldırım, 2014, s. 76).

xv Halaçoğlu'nun verdiği listede, kalan Ermenilerin sayısı bulunmamaktadır. Bu hususla ilgili ayrıca bkz. Altıntaş, s. 92.

xvi Rus Kafkas Ordusu'nun askeri kaygllarla ve titiz bir araştırma ile yaptığı tespitlere göre 1912 yılında Erzurum'da 119.648 Ermeni bulunmaktadır. (Sertçelik, 2015, s. 333).

xvii Bir kısım Ermenilerin tehcirden müstesna tutulmak için ihtida ettikleri görülmektedir. Dâhiliye Nezareti'nden Kayseri'ye yazılan 13 Temmuz 1915 tarihli bir şifrede ihtida eden Ermenilerin dahi tehcirlerinin tehir edilmemesi uyarıs1 yapılmıştır. Bkz. Osmanlı Belgelerinde Ermenilerin Sevk ve İskânı (1878-1920), Başbakanlık Devlet Arşivleri Genel Müdürlüğü Yayınları, Ankara 2007, s. 198. Ancak bu uyarının her yerde dikkate alındığını söylemek güçtür. Zira Erzurum'da ihtida eden bir kısım Ermenilerin sicile kaydedilirken eski Ermeni aile isimlerinin tasrih edilmediği, yalnız Müslüman olduktan sonra aldıkları isimlerle kaydedildikleri bildirilmiştir (3 Şubat 1916) (BOA. DH. ŞFR. 507/118)

xviii Tehcir neticesinde Diyarbekir'de bulunan yaklassı 56.000 Ermeni'den sadece askeri imalat yapabilecek 200 Ermeni'nin kalmış olması Erzurum'da yalnız 500 Ermeni kalmış olduğu kaydını anlaşılır kılmaktadır. Ayrıntılı bilgi için bkz. Aktar, Kırmız1, 2013, ss. 289-323.

xix Buradaki ifadeler Erzurum Kongresi'nden kısa bir süre kaleme alınmış olup, dönemin şartları muvacehesinde ahalideki birlik ve beraberlik üzerinde vurgu yapılması anlamlı bulunmuştur. 